\title{
Kurikulum Pendidikan Islam Para Sahabat: Satu Sorotan
}

\author{
Ahmad Firdaus Mohd Noor ${ }^{1}$, Khairunnisa A Shukor ${ }^{2}$ \\ ${ }^{1}$ Akademi Pengajian Islam Kontemporari UiTM Cawangan Perak, Kampus \\ Seri Iskandar, 32610, Perak \\ ${ }^{2}$ Akademi Tamadun Islam, Fakulti Sains Sosial dan Kemanusiaan, UTM \\ Skudai, 813100, Johor \\ email:1afirdaus2209@gmail.com, ${ }^{2}$ pn.khairunnisa.a.shukor@gmail.com
}

\begin{abstract}
Abstrak
Kurikulum mempunyai pelbagai definisi mengikut pemikiran dan tafsiran para sarjana pendidikan. Definisi ini boleh dibagimenjadi beberapa kategori.Antara kategorinya ialah berasaskan rancangan di peringkat sekolah, pendidikan, objektif, luas atau sempit, dan sebagainya. Walaubagaimanapun jangan kita lupa sejarah kedatangan Islam membawa satu kurikulum yang sangat lengkap dalam setiap aspek kehidupan. Kurikulum al-Quran, Hadis, Zaman Para Sahabat, Zaman Abbasiah, Zaman Umayyah, Zaman Fatimiyah hingga Uthmaniyah, dan pelbagai contoh kurikulum daripada pelbagai sarjana Islam. Kertas kerja ini membincangkan mengenai "Kurikulum Pendidikan Islam Zaman Sahabat".

Kata Kunci : Kurikulum, pendidikan Islam, sahabat, kuttab.
\end{abstract}

\section{Abstract}

There are many definitions of curriculum based on the thinking and interpretation of experts and scholars in education. These definitions can be devided into different categories. The categories are based on planning at school level, education, objectives, wide or narrow, and so on. Nevertheless, we should have never forgotten the history of the arrival of Islam, when a complete curriculum in every aspect of life was brought. There are consisted of curriculum of the Quran, Hadith, during the time of the Companions, the Abbasids and Umayyads, and all curriculum contributed by the scholars in Islam. This paperwork discusses the curriculum of Islamic Education in the time of the Companions.

Kata kunci: Curriculum, Islamic Education, the Companion, kuttab 


\section{A. Pendahuluan}

Pendidikan merupakan sesuatu yang penting dan telah wujud sejak awal lagi, sama ada secara langsung atau tidak langsung. Memandangkan pada zaman dahulu, pendidikan secara sistematik belum lagi wujud, rekod jugak sukar untuk diperolehi. Pendidikan juga boleh diklasifikasikan kepada tiga, iaitu secara lisan, bertulis dan praktikal. Pendidikan secara lisan lebih awal dipraktikkan dengan adanya pendidikan dalam bentuk nasihat, pendapat atau perbahasan. Ianya juga diikuti oleh pendidikan secara praktikal. Hampir kesemua pendidikan memerlukan kolaborasi pendidikan secara lisan dan praktikal. Tetapi, sistem rekod diwujudkan agak lewat mengikut perkembangan sistem tulisan dan rekod.

Pendidikan tidak bermaksud hadir ke sekolah dan berjaya dalam pelajaran. Thomas Edison, Hanry Ford atau mereka yang berjaya dan hebat bukanlah orang yang tamat persekolahan (Webb, 2000). Mereka adalah orang yang membuat kajian dan mengumpul data, di mana persekitaran persekolahan yang menetapkan pelajar di dalam kelas tidak sesuai untuk mereka. Oleh itu, apakah sebenarnya pendidikan itu?

Pendidikan membawa maksud yang luas. Hampir setiap tamadun mempunyai maksud dan sistem pendidikan yang tersendiri. Di dalam bahasa Inggeris, pendidikan atau education, yang tergolong dalam kumpulan kata nama bermaksud, 'suatu perlakuan atau proses pembelajaran, seperti yang ditentukan oleh kemahiran belajar' (Zimmerman, 2005). Ia juga bermaksud 'mana-mana proses, sama ada formal atau tidak, yang membentuk potensi organisma yang semakin matang' (Columbia Encyclopedia: Education, 2008). Kedua-dua definisi merujuk kepada pembentukan manusia bagi persediaan meningkat dewasa. Kelemahan definisi ialah ia tidak merujuk kepada kewujudan ilmu-ilmu baru yang membawa pembaharuan kepada perkembangan tamadun. Zimmerman juga hanya fokus pada proses pembelajaran, tetapi ia hanya pada segi bahasa. Tidaklah pula dihuraikan dari segi aplikasinya. 
Berlainan pula dalam bahasa Latin di mana pendidikan, atau perkataan asalnya, e-ducere, bermaksud membawa jalan keluar (The Meaning of Education, 2002). Definisi ini agak terhad. Ia tidak menerangkan maksud yang boleh diaplikasikan kerana pelajar tidak lagi perlu dipandu untuk keluar dari kesesatan dan kegelapan. Pendidikan di zaman Greek dan Roman dahulu adalah untuk membawa masyarakat keluar dari kegelapan dan menyedarkan mereka betapa pentingnya ilmu. Kini, pendidikan lebih untuk melengkapkan diri memahami isu semasa dan mengikuti era teknologi dan sains.

Di dalam bahasa Arab pula, pendidikan diistilahkan sebagai ta'lim, tadris, tarbiyah atau ta'dib iaitu mengajar, memelihara atau memberi ilmu (Nordin \& Othman, 2008). Penulis menerangkan bahawa proses pendidikan terjadi dengan memberi ilmu dalam membentuk adab dan perkembangan bakat. Di sini dapat kita lihat bahawa penulis membawa elemen adab dan bakat dalam definisinya.

Terdapat juga ilmuan Islam yang menampilkan diri dalam bidang ini. Mereka menyatakan adanya dua bidang yang perlu ditekankan, duniawi dan ukhrawi. Teori-teori Islam dapat dilihat dan dikaji dan di antaranya ialah Ibn Khaldun, al-Ghazali Abdul Ghani al-Nawawi dan ramai lagi.

Al-Mawardi mencadangkan bahawa ilmu dunia dan akhirat perlu digabungkan untuk pendidikan Islam. Al-Ghazali juga mengutarakan tentang teori dan praktikal dalam pendidikan Islam untuk mencapai tahap ideal dalam menjadi Muslim yang sejati. Di dalam penulisan Muqaddima, Ibnu Khaldun berpendapat bahawa pendidikan itu merangkumi kedua-dua belah pihak iaitu secara individu dan berkumpulan, pertamanya dari segi nilai-nilanya dan yang kedua dari segi ilmunya dan tahu-bagaimana (Cheddadi, 1994). Kupasan tentang pendidikan dalam Muqaddima bukan secara umum, tetapi kupasan yang komprehensif dan terperinci. 


\section{B. Pembahasan}

\section{B.1 Pendidikan di awal Islam}

Kebangkitan Muhammad bin Abdullah, bermulalah satu era baru dalam era pendidikan. Pendidikan ini bersumberkan wahyu. Kelima-lima ayat dalam Surah al-'Alaq merupakan isyarat dan perintah yang diturunkan dalam bidang pendidikan.

"Bacalah dengan (menyebut) nama Tuhanmu yang
menciptakan(1)Dia telah menciptakan manusia dari segumpal
darah(2)Bacalah dan Tuhanmulah Yang Maha
Pemurah(3)Yang mengajar manusia dengan perantaraan
kalam(4) Dia mengerjakan kepada manusia apa yang tidak
diketahuinya(5)" (Surahal-'Alaq, 96:1-5)

Mengikut sejarah permulaan pendidikan dalam Islam, ayat ini ialah wahyu yang pertama diturunkan sebagai satu ajakan dan penekanan bahawa menuntut ilmu itu suatu tuntutan. Hal ini disokong pula dengan hadis Nabi s.a.w. yang menyatakan:

"Menuntut ilmu adalah fardhu bagi Muslimin dan Muslimat." (HR Ibnu Majah, Sunan Ibnu Majah, h. 220)

Ayat ini mendidik orang yang beriman supaya menjadi orang yang berilmu(Mahmud, 1985). Pendidikan Islam adalah pendidikan al-Quran. 'Tempat yang dipilih untuk mengajar pendidikan al-Quran ialah dirumahnya sendiri' (Ariffin, 1993). Kemudian, diikuti pula oleh rumah AlArqam bin Abi Al-Arqam (Syalaby, 1954). Setelah dipindahlan ke Madinah pada tahun $610 \mathrm{H}$, rumah baginda dijadikan tempat mengajar. Apabila Masjid Nabawi dibina, masjid ini dijadikan tempat mengajar, iaitu 'setiap hari dan seminggu sekali bagi kaum wanita' (Kinnany, 1980).

Baginda membaca ayat-ayat al-Quran yang diterimanya, menerangkan maksudnya, dan kemudian menyuruh sahabat-sahabat menghafaz ayat-ayat tersebut. Sahabat-sahabat pula mengajar keluarga 
mereka di rumah masing-masing. Sahabat-sahabat berusaha bersungguhsungguh menghafaz ayat-ayat yang diajarkan oleh Nabi s.a.w. Setiap malam mereka membaca al-Quran dan mengulang-ulang bacaan yang dihafaz.Al-Saboony (1985) melaporkan bahawa jika kita berjalan diwaktu malam di Madinah melalui rumah-rumah sahabat, kita akan mendengar dengungan yang hebat seperti bunyi lebah di dalam sarangnya, itulah dengungan suara orang membaca al-Quran.

Terdapat satu golongan yang digelar Ahlus-Suffah/ IkhwanusSuffah yang berusaha mendalami ilmu-ilmu Islam berdasarkan al-Quran dan Sunnah Rasulullah s.a.w. Jumlah mereka lebih kurang 20 orang, ada pendapat yang mengatakan 40 orang (Al-Naqib, 1984). Tugas mereka ialah membuat penyelidikan, mendalami ilmu, dan mengajar. Apa yang dapat kita lihat di sini ialah bidang penyelidikan (research and development) telah wujud sejak zaman awal Islam lagi. Tetapi, proses yang dijalankan tidaklah begitu kompleks seperti yang ada sekarang. Ahlus-Suffah sentiasa berada di suatu sudut di dalam Masjid al-Nabawi membuat kajian dan mengajar. Dengan perintah Rasulullah s.a.w. mereka tidak perlu pergi berperang, sebaliknya mereka tetap berada di masjid mendalami ilmu dan mengajar orang lain.

"Hanyalah orang-orang yang memakmurkan masjid-masjid Allah ialah orang-orang yang beriman kepada Allah dan hari kemudian, serta tetap mendirikan solat, menunaikan zakat dan tidak takut (kepada sesiapun selain kepada Allah), maka merekalah orang-orang yang diharapkan termasuk golongangolongan yang mendapat petunjuk" (Surah al-Taubah, 9:18)

Ahlus-Suffah terdiri dalam kalangan sahabat yang mahir dalam beberapa bidang, contohnya:
Said bin Al-'As
-Penulisan
Ubadah bin Sanid
-Bacaan al-Quran
Ubai bin $\mathrm{Ka}$ 'ab
-Bacaan al-Quran 
Zaid bin Thabit $\quad$-Faraid

Mu'az bin Jabal -Fiqh

Umar al-Khattab -Harta benda

\section{B.2 Pendidikan Islam Selepas Rasulullah S.A.W.}

Usaha pendidikan Islam tidak terhenti sebaik sahaja kewafatan Nabi Muhammad s.a.w. Usaha-usaha ini disambung pula oleh sahabat-sahabat yang mengambil alih tugas baginda memimpin umat Islam. Tidak dapat dinafikan mereka kehilangan satu sumber rujukan utama, tetapi Rasulullah s.a.w. telah membuat persediaan yang rapi sebelum pemergian baginda. Sahabat-sahabat telah dilengkapi dengan ilmu agama yang cukup mantap agar di kemudian hari, mereka dapat menjadi sumber rujukan kepada seluruh umat Islam.

Di awal pendidikan di zaman Khulafa al-Rashidin, tiada langkahlangkah khusus yang diwujudkan bagi menyelaraskan pendidikan Islam di peringkat yang lebih kompleks. Ketika itu pula, empayar Islam sedang gamat dihujani dengan nabi-nabi palsu. Oleh itu, usaha yang terulang yang dilakukan sebaik sahaja perlantikan Saidina Abu Bakar ialah pembukuan alQuran menjadi satu mashaf.

Para sahabat telah menumpukan perhatian mendidik kaum Muslimin di samping pada masa yang sama mentadbir negara (Darusalam, 2004). Tiada sistem pendidikan yang seragam diwujudkan. Tetapi, sahabat-sahabat meneruskan pendidikan Islam dengan mengajar kanak-kanak. Dari situ, wujudnya kuttab yang menjadi pusat pendidikan Islam. Kuttab yang sebelum ini mengajar menulis dan membaca, ditambah lagi dengan kuttabkuttab (katatib) khas untuk belajar al-Quran (Ahmad, Falsafah dan Sejarah Pendidikan Islam, 2004).

Sahabat-sahabat meneruskan usaha pendidikan Islam ini berteraskan al-Quran dan Sunnah. Sepertimana yang telah dinyatakan oleh Rasulullah s.a.w. sendiri: 
"Aku tinggalkan kepada kamu dua perkara yang kamu tidak akan sesat jika berpegang kepada keduanya; al-Quran dan alSunnah."

Oleh itu, dengan berpegang teguh kepada al-Quran dan Sunnah, dapatlah kita simpulkan bahawa sistem pendidikan itu adalah mengikut susun-atur al-Quran dan Sunnah. Di zaman sahabat, sistematik dalam pendidikan dapat dilihat melalui hasilnya lebih daripada sistem itu sendiri.

\section{B.3 Kronologi Perkembangan Pendidikan Islam pada Zaman Khulafa'al-Rashidin.}

Masa Khalifah Abu Bakr al-Siddiq: Dengan kompilasi al-Quran dalam bentuk mashaf, sistem pendidikan Islam menjadi lebih sistematik dan teratur. Sungguh pun terdapat keraguan pada awalnya, akhirnya al-Quran dikodifikasikan dan menjadi sumber rujukan yang terulung dan terpelihara.

Masa Khalifah Umar al-Khattab:Khalifah Umar al-Khattab amat menggalakkan penyebaran ilmu dalam kalangan umat Islam. Kewujudan kuttab-kuttab hampir di seluruh empayar Islam melambangkan kemegahan pendidikan Islam pada ketika itu. Sahabat-sahabat di hantar ke seluruh tanah jajahan Islam sebagai langkah untuk mendidik umat Islam dan mengembangkan Islam ke seluruh dunia. Pendidikan dibuka luas, baik dari segi dunia mahupun akhirat.

Masa Khalifah Uthman ibn 'AffanPembukuan semula al-Quran mengikut Rasm 'Uthmani membuka jalan kepada penyelarasan pendidikan Islam di peringkat antarabangsa, seluruh umat Islam khususnya. Khalifah Uthman ibn 'Affan juga telah menyumbang sebahagian besar daripada hartanya untuk dibelanjakan di jalan Allah, membantu meluaskan pendidikan Islam terutama dari segi kewangan.

Masa Khalifah Ali ibn Abi TalibKhalifah Ali ibn Abi Talib sendiri adalah orang yang disanjung kerana ilmunya. Nabi s.a.w. bersabda: "Aku adalah kota ilmu dan Ali adalah pintu gerbangnya." 


\section{B.4 Pembukuan Kitab al-Quran.}

Setelah kewafatan baginda Nabi s.a.w., wujudnya nabi-nabi palsu dalam jumlah yang agak ramai. Bilangan ini meningkat dari masa kesemasa kerana umat Islam pada masa itu telah kehilangan tempat rujukan yang agung dan mereka amat memerlukan seseorang untuk mengisi kekosongan itu. Tambahan pula, sebilangan besar huffaz telah syahid dalam perang alYamamah, memerangi orang yang murtad (Ahmad, 2000).

Kemudian, Saidina Umar al-Khattab berjumpa dengan khalifah yang pertama, Saidina Abu Bakar al-Siddiq, bagi melahirkan rasa kebimbangan terhadap masa depan umat Islam. Beliau mencadangkan pembukuan al-Quran. Saidina Abu Bakar yang pada awalnya enggan, dikhuatiri melakukan bid'ah, akhirnya bersetuju melihatkan keadaan huruhara yang berlaku ketika itu. Apabila dinyatakan kepada Zaid bin Thabit juga, dia tidak menerima tetapi apabila diterangkan oleh Saidina Abu Bakar tentang kebaikan-kebaikan di masa hadapan, beliau akhirnya menerima juga (Anwar Mag, 2004).Sekalipun beliau adalah penghafal al-Quran seluruhnya, tetapi untuk kepentingan pengumpulan al-Quran yang sangat penting bagi umat Islam itu, beliau masih memandang perlunya memadankan atau menyesuaikan hafalan atau catatan sahabat-sahabat yang lain dengan disaksikan oleh dua orang saksi (Azarqoni, 2001).

Zaid bin Thabit sangat teliti dengan penyusunan surah-surah. Dia amat berhati-hati dengan surah-surah yang telah dimansukhkan dan yang tidak mutawatir riwayatnya. Dengan demikian, ayat-ayat al-Quran yang diturunkan itu seluruhnya telah ditulis oleh Zaid bin Tsabit dalam lembaran-lembaran, dan diikatkannya dengan baik dan benar, tersusun menurut urutan ayat-ayatnya sebagaimana yang telah ditetapkan oleh Rasulullah (Azarqoni, 2001).

Dengan pembukuan al-Quran, sistem pendidikan Islam menjadi lebih mudah. Kanak-kanak diajar al-Quran seawal usia. Lahirnya huffaz generasi baru dan Islam terpelihara sehingga kini. Pendidikan al-Quran 
kemudiannya diluaskan lagi dengan ilmu-ilmu memahami al-Quran seperti balaghah, ibadah, fiqh, 'aqidah, dan lain-lain lagi.

\section{B.5 Khalifah Umar al-Khattab dan Perkembangan Kurikulum Pendidikan Islam.}

Di antara keempat-empat khualafa' al-rasyidin, perkembangan ilmu dapat dilihat ketika pemerintahan Khalifah Umar al-Khattab. Beliau menggalakkan penyebaran ilmu dalam kalangan umat Islam terutamanya dalam ilmu al-Quran. Khalifah sendiri memastikan setiap apa yang dikatakannya disahkan oleh al-Quran sendiri. Keagungan al-Quran cukup terserlah sehinggakan setiap apa yang dilakukan, diikrarkan dan diniatkan adalah berlandaskan al-Quran dan Sunnah. Rasulullah s.a.w. sendiri menyatakan, "Sekiranya ada nabi selepas aku, ternyata orang itu adalah Umar.'Dikenali sebagai pemisah hak dan batil, beliau memastikan setiap ilmu Islam didalami dengan baik. Sikap yang nyata ini membuktikan bahawa Umar al-Khattab ialah pelajar yang baik dan mendalami ilmu Islam dari hati bukan akal semata. Oleh sebab itulah, beliau berkehendakkan setiap muslim menjadi pelajar dan pengajar ilmu yang suci ini.

Ketika pemerintahan Umar al-Khattab, beliau telah menghantar sahabat-sahabat dan ulama' sebagai wakil ilmu di masjid-masjid diseluruh empayar Islam. Dikatakan dalam tahun 17 Hijrah, beliau telah menghantar para guru ke setiap wilayah Islam untuk mengajar di masjid pada setiap hari Jumaat (Darusalam, 2004).

Ibn As'ud pernah berkata tentang Umar (Testament and Assessment of Umar, 2004):"“Sekiranya kebijaksanaan Umar di atas neraca dan ilmu pada benda-benda hidup di atas muka bumi terletak di satu bahagian, kebijaksanaan Umar lebih berat dari itu dan sesungguhnya pada pemikiran orang ramai, Umar membawa 9 per 10 kebijaksanaan dunia.”Bidang keilmuan dibuka luas ketika itu. Bidang ini tidak hanya tertumpu pada ilmu ukhrawi, malah terbuka juga kepada bidang akademik dan lain-lain. Ketika 
itulah, wujudnya ahli-ahli ilmuan yang mahir dalam bidang-bidang ilmu astrologi, mantik, dan banyak lagi.

Pada zaman Khalifah Umar al-Khattab dikatakan oleh para pengkaji sejarah bahwa semua wilayah yang berada di bawah pentandbiran khilafah baginda mempunyai pusat pengajian dan pendidikan Islam (Darusalam, 2004). Walaupun Umar al-Khattab semasa menjadi Khalifah pernah mengeluarkan perintah supaya mengajar anak-anak berenang, menunggang kuda, bersyair dan sastera Arab, maka itu tidaklah dianggap melanggar sunnah, bahkan adalah merupakan sebagai tambahan kepada kurikulum tradisional yang sedia ada (Syalaby, 1954).Hafazan al-Quran turut dilaksanakan.

Pada zaman Umar al-Khattab juga terciptanya Kalendar Hijriyah. Kalendar ini membantu perluasan ilmu ketika itu kerana pelan-pelan dan struktur cadangan untuk melakukan sesuatu dapat disusun dengan teratur. Hal ini dipersetujui dan dibincangkan didalam majlis ilmu. Terwujudnya majlis ilmu juga membantu apabila dapat dilakukan secara musyawarah dan Mufakat. Di sini, dapat dilihat research and development $(R \& D)$ wujud ketika pemerintahan Umar al-Khattab. Kemajuan ilmu ketika itu dilihat dalam bentuk usaha dan perancangan yang rapi. Saidina Umar bukan sahaja berilmu untuk dirinya sendiri, malah digalakkan menuntut ilmu itu bersama-sama dengan sahabat-sahabat dan umat Islam yang lain.

\section{B.6 Kuttab dalam Pendidikan Islam.}

1. Pengenalan kepada Kuttab.

Kuttab mula terpancar pada zaman Umar al-Khattab. Walaupun ada yang mengatakan kuttab bermula sejak zaman Nabi s.a.w. tetapi buktinya kurang jelas. Yang jelas, pada zaman Nabi s.a.w. kuttab tulisan dan bacaan banyak ditulis oleh orang bukan Islam, sebaliknya orang Nasrani(Al-Naqib, 1984). Ada juga yag mengatakan kuttab pertama ialah di rumah al-Arqam 
Abi al-Arqam. Kuttab-kuttab boleh dijumpai hampir di seluruh negara Islam pada kurun ke-8.

Pada zaman kemajuan Islam, kira-kira tahun 1066M, sekolahsekolah rendah atau kuttab, telah tersebar dengan luasnya di seluruh negeri Islam (Syalaby, 1954). Semua negeri Islam telah mempunyai kuttab. Kurikulum di kuttab ini telah berubah dan berlainan antara satu tempat dengan tempat yang lain. Kittab yang dahulunya mengajar al-Quran sahaja telah ditambah dengan beberapa pelajaran lain seperti penulisan khat, pengajian hadis, Bahasa Arab, dan lain-lain lagi.

Di zaman khalifah Umar al-Khattab r.a., beliau dengan terusmenerus menyeru ibubapa supaya mengajar anak-anak dan menggalakkan orang awam yang pandai menulis dan membaca serta mempunyai ilmu alQuran supaya tampil ke hadapan membuka sekolah pensendirian kuttab (alAroosi, 1980).Kurikulumnya mengajar al-Quran. Umar yang menyuruh diajar anak-anak berenang, menunggang kuda, dan mempelajari syair-syair Arab (Syalaby, 1954).

Terdapat kuttab khas yang diadakan di istana khalifah atau rumahrumah menteri untuk anak-anak mereka yang merupakan kelas khas. Kurikulum kelas ini ditentukan oleh khalifah sendiri, demikian juga dengan gurunya.

2. Kurikulum di Kuttab.

Kuttab pada awalnya dikhaskan kepada kanak-kanak lelaki, seawal usia 4 tahun. Pelajarannya tertumpu kepada pembelajaran al-Quran dan bahagian-bahagian ibadah, seperti solat dan puasa. Menghafaz al-Quran ialah kurikulum utama.Pendekatannya agak tegas dan wujudnya sistem pemantauan salah laku disiplin. Hukuman sudah mula diperkenalkan.Sebaik sahaja menghafaz al-Quran, pelajar boleh meneruskan pengajian di peringkat yang lebih tinggi dengan arahan yang lebih kompleks.

3. Sistem pendidikan di Kuttab.

Guru-guru membaca ayat-ayat al-Quran kepada pelajar (imla') dan pelajar menulis di atas luh. Setelah itu, guru akan melihat tulisan murid- 
murid dan membetulkannya jika ada kesalahan. Guru membacanya sekali lagi dengan diikuti oleh murid. Kumudian murid akan pergi ke tempat lain dan membacanya sehingga hafal. Setelah hafal dengan fasih, mereka akan datang semula kepada guru dan menghafalnya dihadapan guru (tasmi'). Jika ada kesalahan, guru akan betulkan dan jika tiada, maka ayat-ayat itu dipadam dan ditulis ayat baru untuk dihafal (Al-Ahwany, 1983).

Selepas kanak-kanak tamat menghafaz al-Quran di kuttab, mereka akan menyambung pengajian mereka atau mendalami ilmu Islam di masjid. Di masjid, mereka akan mempelajari hukum-hukum agama, prinsip-prinsip Islam, dan akidah, bahasa arab, nahu, balaghah, dan sebagainya (AlIbrasyy, 1976). Di dalam masjid, pelajar duduk di dalam bulatan atau separuh bulatan, bersama dengan gurunya. Adakalanya guru membaca nas dan adakalanya murid membaca dan guru menghuraikannya.

Mereka mengamalkan ajaran yang difahami daripada ayat-ayat yang dihafaz.Al-Badry (1984) melaporkan bahawa dengan cara inilah Nabi s.a.w. mengajar sahabat-sahabatnya, dan dengan cara yang sama juga sahabatsahabat mengajar keluarga dan pengikut-pengikut mereka.

Berdasarkan kepada hakikat ini, dapat dibuat satu pegangan bahawa al-Quran yang diajar di kuttab di zaman sahabat dan seterusnya adalah mengikut cara yang sama, kurikulumnya sama, membaca, mamahami, mengahafaz, dan menghayati. Tradisi ini diteruskan dan merupakan satu sunnah, dan sahabat tidak pernah melanggar sunnah.

4. Metodologi.

Metodologi utama pendidikan di kuttab ialah hafazan dan tasmi'.Para sahabat menggunakan tiga metodologi utama dalam pendidikan di kuttab (Azami, 1978; Jasmi \& Che Noh, 2013), yaitu:

\section{Menglafazkan}

Sudah menjadi kebiasaan para sahabat menghafaz al-Quran dan hadis di masjid bersama-sama Rasulullah s.a.w. Oleh itu, mereka 
meneruskan sunnah ini sebagai salah satu metodologi pendidikan yang dianggap berkesan pada masa itu.

2. Mencatat.

Terdapat beberapa sahabat di mana hadis mereka ditulis olehpara pelajar; Abu Hurairah, Ibn Umar, Anas ibn Malik, Ibn Abbas, dan ramai lagi.

3. Mempraktekkan.

Khulafa' al-Rasyidin amat mahir dalam setiap ilmu yang mereka kuasai baik dari segi teori mahupun praktikal. Mereka memastikan apa yang dipelajari bukan hanya teori, tetapi teori itu didalami dan difahami dengan baik. Kemudian, ilmu itu dipraktiskan mengikut Sunnah.

\section{Penutup}

Kesimpulannya pendidikan seharusnyanya amat ditekankan dalam Islam. Hal ini dapat dilihat berdasarkan penurunan wahyu yang pertama diturunkan. Melalui ilmu juga martabat manusia akan diangkat dan dimuliakan oleh Allah. Orang yang berilmu akan menjadi pewaris kepada nabi dan menjadi sumber rujukan umat Islam di mana saja mereka berada. Kurikulum pendidikan Zaman Sahabat merupakan sebagian tanda kehebatan ilmu pendidikan dalam Islam. Hal itu, menjadi tanggungjawab manusia hari ini mengangkat semula dan mengetengahkan metodologi hebat dalam kurikulum Zaman Sahabat yang telah berjaya melahirkan sahabat-sahabat ilmuwan agung Islam suatu ketika dahulu untuk diaplikasikan dan disesuaikan dalam sistem hari ini bagi meneruskan kelangsungan kehebatan umat Islam. 


\section{Daftar Pustaka}

Ahmad, M. Y. (2000). Sejarah dan Kaedah Pendidikan al-Quran. Kuala Lumpur: Penerbit Universiti Malaya.

Ahmad, M. Y. (2004). Falsafah dan Sejarah Pendidikan Islam. Kuala Lumpur: Penerbit Universiti Malaya.

Al-Ahwany, A. F. (1983). At-Tarbiyah fil Islam. Qahirah: Dar al-Ma'arif. al-Aroosi, M. (1980). Islamic Curriculum and the Teacher. Jeddah: King Abdul Aziz University.

Al-Ibrasyy, M. A. (1976). At-Tarbiyah Al-Islamiyah wa-falasafatuha. Qahirah: Dar Al-Fikri Al-Arabi.

Al-Naqib, A.-R. A. (1984). Buhuth fi at-Tarbiyah al-Islamiyah. Qahirah: Dar Al-Fikr Al-Araby.

Anwar Mag, R. (2004). Samudra al-Quran. Bandung: Pustaka Setia.

Ariffin, A. H. (1993). At-ta'lim fi asri al-rasul wal-khulafa ar-rashidin. Kuala Lumpur: Universiti Islam Antarabangsa Malaysia.

Azami, M. (1978). Studies in Hadith Methodology \& Literature. Amer Trust Publication.

Azarqoni, M. A. (2001). Manahilul Quran fi 'Ulumil Quran. Darul Hadist: Kaherah.

Cheddadi, A. (1994). IBN KHALDUN (A.D. 1332-1406/A.H. 732-808). Prospects: the quarterly review of comparative education, 1.

Columbia Encyclopedia: Education. (2008). Retrieved 12 March, 2009, from Bartleby.com: http://www.bartleby.com/65/ed/educatio.html

Darusalam, G. (2004). Pedagogi Pendidikan Islam . Kuala Lumpur: PrinAd Sdn. Bhd. 
Kinnany, A. H. (1980). Producing Teachers for Islamic Education. Jeddah: King Abdul Aziz University.

Jasmi, K. A. \& Che Noh, M. A. (2013). Sejarah, Kaedah, serta Model Pengajaran dan Pembelajaran al-Quran (History, Methods, and Models of Teaching and Learning of the Quran) in Bengkel Pemulihan dan Pengayaan Pengajaran dan Pembelajaran (PdP) alQuran SRA JAWI (Remedial and Enrichment Workshop for Teaching and Learning Quran SRA JAWI) at Lecture Hall, Masjid Negara, Jalan Perdana 50480, Kuala Lumpur on 28-29 October 2013, pp. 1-17.

Mahmud, A. H. (1985). Al-Quran wan-Nabiy. Al-Qahirah: Dar al-Ma'rif.

Nordin, A. B., \& Othman, I. (2008). Falsafah Pendidikan dan Kurikulum. Tanjung Malim: Quantum Books.

Syalaby, A. (1954). HIstory of Muslim Education. Beirut: Dar Al-Kashshaf.

Testament and Assessment of Umar. (5 November, 2004). Retrieved 10

February, 2009, from Witness-pioneer.org Web site:

http://www.witness-

pioneer.org/vil/Articles/companion/20_umar_bin_al_khattab.htm\#H oly\%20Prophet $\% 27 \mathrm{~s} \% 20$ Assessment $\% 20$ Of\%20Umar

The Meaning of Education. (2002). Retrieved 12 February, 2009, from Teacher's Mind Resources:

http://www.ask.com/bar?q=Definition+of+Education\&page=1\&qsrc $=6 \& \mathrm{ab}=2 \& \mathrm{u}=\mathrm{http} \% 3 \mathrm{~A} \% 2 \mathrm{~F} \% 2 \mathrm{Fwww} \cdot$ teachersmind.com $\% 2 \mathrm{Feducat}$ ion.htm

Webb, R. L. (2000). What is education? Retrieved 12 March, 2009, from Motivation Tool Chest: http://www.ask.com/bar?q=what+is+education $\% 3 F \&$ page $=1 \& q \mathrm{src}=$ $0 \& \mathrm{ab}=1 \& \mathrm{u}=\mathrm{http} \% 3 \mathrm{~A} \% 2 \mathrm{~F} \% 2 \mathrm{Fwww}$.motivationtools.com\%2Fyouth\%2Fwhat_is_education.htm 
Zimmerman, M. (2005). New Online Emotional Literacy Education Course by Mark Zimmerman . Retrieved 12 March, 2009, from Dictionary Information: Definition Education:

http://www.ask.com/bar?q=Definition+of+Education\&page $=1 \& \mathrm{qsrc}$ $=6 \& \mathrm{ab}=4 \& \mathrm{u}=\mathrm{http} \% 3 \mathrm{~A} \% 2 \mathrm{~F} \% 2 \mathrm{Fwww} \cdot$ selfknowledge $\cdot \operatorname{com} \% 2 \mathrm{~F} 3011$ 9.htm 